\title{
Dampak Moderasi Moral Perpajakan pada Hubungan Perceived Probability of Audit dan Sanksi terhadap Perilaku Kepatuhan Pajak Usaha Mikro, Kecil dan Menengah (UMKM) (Studi Empiris pada UMKM Daerah Istimewa Yogyakarta)
}

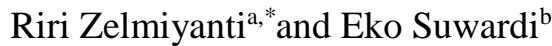 \\ ${ }^{\mathrm{a}}$ Manajemen Bisnis, Politeknik Negeri Batam, riri@ polibatam.ac.id, Indonesia \\ ${ }^{\mathrm{b}}$ Faculty of Economics and Business, Universitas Gajah Mada, Indonesia
}

\begin{abstract}
This study aims to explore more carefully and in detail the influence of economic factors (perceived probability of audits and sanctions) and behavioral factors (moral) of the tax compliance of SMEs in Indonesia. Research on tax compliance has been done, but still a bit that combines economic and behavioral factors. Previous research mostly done on large companies and to individual taxpayers. The current study was conducted on SME entrepreneurs. This study tried to moderate the tax morale in relation to perceived probability of audits and sanctions against tax compliance. Samples in this study were individual taxpayers from SMEs in Yogyakarta. The research data was collected through a survey. Questionnaires had been processed in this study were around 118 questionnaires. Testing the hypothesis in this study used multiple regression analysis and analysis regression moderated. Regression analysis tool used is IBM SPSS 19.0. The results of this study indicate that the perceived probability of audits and sanctions have a direct impact on tax compliance. This study was not able to prove the moral moderating effect of taxation on the relationship perceived probability of an audit of tax compliance. This study also can not prove the moral moderating effect of taxation on the relationship sanctions on tax compliance.
\end{abstract}

Keywords: tax compliance, SMEs, perceived probability of audit, tax and moral sanctions

\section{Pendahuluan}

Indonesia merupakan negara yang mengandalkan pendapatan dari sektor pajak. Total pendapatan Indonesia menunjukkan bahwa $73 \%$ pendapatan berasal dari sektor pajak (total pendapatan Rp1.338.109.629.172.958,- sedangkan dari sektor pajak Rp980.518.133.319.319,- LKPP, 2012). Indonesia pada tahun 2012 mengalami defisit anggaran sebesar Rp153,30 Trilliun. Pengurangan angka defisit dapat dilakukan dengan menggali sektor pajak. Adanya Peraturan Pemerintah (PP) Nomor 46 tahun 2013 merupakan salah satu usaha pemerintah meningkatkan pendapatan dari sektor pajak. Kategori usaha yang dikenai PP Nomor 46 tahun 2013 yaitu memiliki omset di bawah 4,8 Milliar Rupiah dikenakan Pajak Penghasilan (PPh) final sebesar $1 \%$. UMKM merupakan suatu usaha yang dikenai PP Nomor 46 tahun 2013.

Berdasarkan statistik UMKM dari Kementerian Koperasi dan UKM (2012) sumbangan PDB (Produk Domestik Bruto) UMKM pada tahun 2012 sebesar

\footnotetext{
*Corresponding author. E-mail: riri@polibatam.ac.id
} 
4.869.568,1 Milyar Rupiah. Pandapatan dari PDB akan berhubungan dengan jumlah potensi pajak yang akan diterima negara. Berdasarkan sumbangan PDB di atas menunjukkan UMKM memiliki potensi pendapatan pajak yang cukup besar sebagai penyumbang pendapatan negara.

Beberapa penelitian terdahulu mencoba menjelaskan beberapa keunggulan UMKM. Campin et al. (2013) menyatakan bahwa UMKM memiliki potensi untuk meningkatkan kesejahteraan masyarakat. Hasil penelitian yang dilakukan oleh Hendrict et al. (1997), pertumbuhan UMKM lebih besar dibanding perusahaan besar. Keunggulan lain dari UMKM adalah menciptakan lapangan pekerjaan baru (Chen et al., 2002 dan Praag, 2007).

Potensi pendapatan dan beberapa keunggulan UMKM di Indonesia ternyata tidak sebanding dengan pajak yang diterima negara dari sektor UMKM. Fuad Rahmany, Direktur Jenderal Pajak (Dirjen Pajak) Kementerian Keuangan menyatakan bahwa hingga akhir tahun 2013 penerimaan pajak yang berasal dari sektor UMKM masih di bawah 2\% atau sebesar Rp 20,5 triliun dari total potensi penerimaan pajak (Zatnika, 2014). Angka tersebut masih jauh dari potensi pajak UMKM, sehingga membuktikan rendahnya tingkat kepatuhan pengusaha UMKM membayar pajak. Molero dan Pujol (2012) menyatakan alasan pengusaha tidak membayar pajak karena manfaat yang dirasakan tidak sebanding dengan biaya yang dikeluarkan.

Kamleitner et al. (2010) menemukan ada tiga aspek kunci yang menyebabkan rendahnya tingkat kepatuhan pajak UMKM, (1) pemilik usaha kecil cenderung melihat lebih banyak kesempatan untuk tidak mematuhi dibandingkan pekerja (2) kurangnya pengetahuan pajak bagi pengusaha kecil dan (3) persepsi pengusaha UMKM bahwa membayar pajak merupakan suatu beban yang mengurangi keuntungan. Kamleitner et al. (2010) juga menyatakan bahwa penelitian kepatuhan pajak di UMKM perlu dilakukan karena sedikit penelitian yang berhubungan dengan perilaku kepatuhan pajak UMKM.

Kepatuhan pajak dapat dilihat perspektif ekonomi dan perilaku. Beberapa penelitian yang melihat kepatuhan pajak dari perspektif ekonomi, seperti Lewis et al. (2009) yang menyatakan bahwa kebijakan audit dapat meningkatkan kepatuhan pajak pada negara-negara yang moral pajaknya rendah seperti kasus Italia. Sander et al. (2008) juga melakukan penelitian mengenai kepatuhan pajak, melihat dari pengaruh akuntabilitas dan kesadaran atas sanksi pada industri konstruksi. Hasil penelitian tersebut menyatakan bahwa kesadaran atas sanksi berpengaruh terhadap kepatuhan pajak.

Penelitian Ghosh dan Crain (1996) melihat tingkat ketidakpatuhan pajak dari etika dan perceived probability of audit dengan metode eksperimen. Hasil penelitiannya menyatakan bahwa semakin tinggi perceived probability of audit menyebabkan ketidakpatuhan pajak semakin rendah. Beberapa penelitian lain menyebutkan bahwa motivasi terbesar kepatuhan wajib pajak ditentukan oleh audit dan sanksi (misalnya Normala, 2004; Hyun, 2005; dan Palil et al. 2011).

Penelitian-penelitian di atas menyimpulkan bahwa motivasi kepatuhan pajak dipengaruhi oleh audit dan sanksi. Hasil penelitian Thurman (1991) dalam Trivedi et al. (2003) berbeda dengan hasil penelitian sebelumnya, yang menyatakan bahwa audit dan sanksi tidak akan cukup menjelaskan derajat kepatuhan pajak. Hasil penelitian Johnson et al. (2010) juga menyatakan bahwa audit (monitoring) tidak akan bisa meningkatkan kepatuhan pajak jika tidak diterapkan dengan beberapa kebijakan.

Audit dan sanksi belum cukup efektif untuk meningkatkan kepatuhan pajak karena probabilitas aktual wajib pajak untuk diperiksa dan diberi sanksi masih cukup rendah. Efek pemeriksaan masih bersifat temporer yaitu hanya dalam periode pemeriksaan. Oleh karena itu, otoritas pajak harus mengkombinasikan perspektif ekonomi dan perspektif perilaku.

Beberapa penelitian terdahulu mencoba menghubungkan perilaku dari aspek moral perpajakan. Moral perpajakan akan menimbulkan motivasi instrinsik seseorang dalam mematuhi dan membayar pajak sehingga berkontribusi untuk menambah pendapatan negara (Torgler dan Schneider, 2004). Penelitian yang dilakukan oleh Cahyonowati (2011) menyatakan bahwa tingkat moral pajak menentukan tingkat kepatuhan seseorang terhadap peraturan perpajakan. Hal tersebut juga dijelaskan oleh Alm dan McClellan (2012) menyatakan bahwa moral merupakan faktor penting untuk meningkatkan kepatuhan pajak.

Beberapa penelitian di atas belum melihat kepatuhan pajak pada sektor UMKM. Budiningrum (2014) melakukan penelitian di UMKM yang menguji norma-norma sosial terhadap kepatuhan pajak. Hasil penelitian Budiningrum (2014) tidak bisa membuktikan bahwa seluruh norma sosial berpengaruh terhadap kepatuhan pajak UMKM di Indonesia. Oleh karena itu, dibutuhkan penelitianpenelitian yang lebih komprehensif mengenai kepatuhan pajak UMKM, khususnya di Indonesia. 
Penelitian yang mengabungkan aspek ekonomi dan aspek perilaku diteliti oleh Liu (2014). Penelitian tersebut menggunakan tiga variabel yaitu norma sosial, probability audit dan sanksi terhadap perilaku pelaporan pajak individu di Amerika. Hasil penelitian menyatakan bahwa norma sosial memiliki pengaruh signifikan pada voluntary compliance, probability audit dan sanksi memiliki pengaruh terhadap enforced compliance. Merujuk dari penelitian di atas, penelitian saat ini akan mencoba mengembangkan penelitian tersebut pada UMKM Indonesia seiring dengan dikeluarkannya PP No 46 tahun 2013, namun dengan mengganti variabel norma sosial menjadi moral perpajakan. Hal ini berdasarkan pernyataan Alm dan McClellan (2012) yang menyatakan bahwa moral merupakan faktor terpenting untuk meningkat kepatuhan pajak. Penelitian ini akan melakukan pengujian secara empiris mengenai dampak moderasi moral perpajakan pada hubungan perceived probability of audit dan sanksi terhadap kepatuhan pajak UMKM.

\section{Tinjauan Literatur dan Pengembangan Hipotesis}

\section{Usaha mikro, kecil dan menengah}

Menurut Undang-Undang No. 20 tahun 2008 tentang Usaha Mikro, Kecil, dan Menengah Pasal 1 menjelaskan bahwa pengertian dan kriteria Usaha Mikro, Kecil, dan Menengah adalah:

1) Usaha Mikro adalah usaha produktif milik orang perorangan dan/atau badan usaha perorangan dengan kriteria kekayaan bersih paling banyak Rp50.000.000,00 tidak termasuk tanah dan bangunan tempat usaha serta hasil penjualan paling banyak Rp 300.000.000,-

2) Usaha Kecil adalah usaha ekonomi produktif berdiri sendiri, dilakukan oleh orang perorangan atau badan usaha yang bukan merupakan anak perusahaan atau bukan cabang perusahaan. Kriteria kekayaan bersih Rp50.000.000,00 Rp500.000.000,- tidak termasuk tanah dan bangunan serta hasil penjualan tahunan Rp300.000.000,00 - Rp2.500.000.000,00

3) Usaha Menengah adalah usaha ekonomi produktif berdiri sendiri, dilakukan oleh orang perorangan atau badan usaha bukan merupakan anak perusahaan atau cabang perusahaan. Kriteria usaha menengah kekayaan bersih Rp500.000.000,00 Rp10.000.000.000,00 tidak termasuk tanah dan bangunan serta memiliki hasil penjualan Rp2.500.000.000,00 - Rp50.000.000.000,00.

Pajak UMKM merupakan salah satu bagian dari pajak pusat. Potensi pajak UMKM sangat tinggi seiring dengan perkembangan UMKM saat ini. Peraturan tentang kewajiban UMKM membayar pajak akan memberikan keuntungan bagi pemilik UMKM karena secara tidak langsung harus membuat laporan omset. Catatan omset tersebut akan membantu pemilik UMKM untuk memantau perkembangan usaha.

\section{Kepatuhan pajak}

Pajak menurut ketentuan umum dan tata cara perpajakan, merupakan kontribusi wajib pajak kepada negara yang terutang oleh orang pribadi atau badan bersifat memaksa berdasarkan undang-undang, dengan tidak mendapatkan imbalan secara langsung dan digunakan untuk keperluan negara bagi sebesarbesarnya kemakmuran rakyat. Menurut kamus Umum Bahasa Indonesia (KBBI), patuh artinya suka dan taat kepada perintah atau aturan, dan berdisiplin. Harinurdin (2009) menjelaskan kepatuhan pajak (tax compliance) adalah sebagai kondisi ideal Wajib Pajak yang memenuhi peraturan perpajakan serta melaporkan penghasilannya secara akurat dan jujur. Dari pengertian di atas dapat simpulkan kepatuhan pajak merupakan kondisi ideal yang harus dilakukan oleh wajib pajak untuk melaporkan penghasilan secara akurat dan jujur, pemungutan pajak juga berdasarkan peraturan atau hukum, serta bertujuan untuk keseimbangan ekonomi.

\section{Moral perpajakan}

Torgler dan Scheider (2004) mendefinisikan moral perpajakan sebagai motivasi intrinsik untuk mematuhi dan membayar pajak sehingga berkontribusi secara sukarela pada penyediaan barang-barang publik. Moral perpajakan merupakan faktor penting yang dapat menjelaskan mengapa orang jujur dalam masalah perpajakan. Moral merupakan motivasi instrinsik seseorang yang akan menentukan keputusan wajib pajak untuk patuh atau tidak.

\section{Perceived probability of audit}

Perceived probability of audit menurut Asnawi et al. (2009) adalah kondisi yang menggambarkan perasaan wajib pajak untuk diperiksa. Perceived probability of audit dalam penelitian ini akan diarahkan pada bagaimana tanggapan seseorang 
ketika dilakukan pemeriksaan, karena belum ada peraturan yang mengatur audit UMKM secara spesifik. Pemeriksaan pajak menurut ketentuan umum perpajakan serangkaian kegiatan menghimpun dan mengolah data, keterana dan bukti yang dilaksanakan secara objektif dan professional berdsarkan standar pemeriksaan untuk menguji kepatuhan pajak wajib pajak dan juga bertujuan untuk melaksanakan ketentuan umum perpajakan. Adanya pemeriksaan akan memberikan gambaran seberapa patuh pembayar pajak terhadap kewajiban perpajakan.

\section{Sanksi perpajakan}

Pengertian sanksi menurut KBBI tanggungan (tindakan-tindakan, hukuman, dsb) yang dapat memaksa orang untuk menepati perjanjian atau menaati ketentuan undang-undang. Menurut Mardiasmo (2006) sanksi perpajakan merupakan jaminan bahwa ketentuan peraturan perundangundangan perpajakan (norma perpajakan) akan dituruti/ditaati/dipatuhi. Sanksi perpajakan merupakan alat pencegah (preventif) agar wajib pajak tidak melanggar aturan perpajakan.

\section{Pengembangan hipotesis}

Beberapa penelitian terdahulu mencoba melihat kepatuhan pajak dari faktor deterrence seperti sanksi dan perceived probability of audit. Penelitian yang dilakukan oleh Liu (2014) membuktikan bahwa perilaku kepatuhan pajak dipengaruhi oleh ketegasan sanksi dan probability audit melalui enforced compliance. Penelitian tersebut sejalan dengan hasil penelitian yang dilakukan oleh Asnawi et al. (2009) bahwa terdapat hubungan yang signifikan antara perceived probability of audit dengan keputusan kepatuhan pajak.

Ghosh dan Crain (1996) juga melakukan penelitian yang berhubungan dengan standar etika dan perceived probability of audit terhadap ketidakpatuhan yang disengaja. Penelitian tersebut dilakukan dengan metode eksperimen terhadap 54 peserta yang memiliki pengalaman dalam pengembalian pajak individu. Hasil penelitan membuktikan bahwa ketika perceived probability of audit tinggi maka tingkat ketidakpatuhan rendah.

Penelitian yang dilakukan oleh Palil dan Ahmad (2011) melihat kepatuhan pajak dari berbagai perspektif. Penelitian tersebut dimulai dari melihat konsep dan definisi kepatuhan pajak dan ketidakpatuhan pajak, pengukuran dari kepatuhan pajak dilihat dari berbagai negara seperti India dan Austria. Hasil penelitian Palil dan Ahmad (2011) membuktikan bahwa peningkatan tingkat audit dan tingkat sanksi dapat meningkatkan tingkat kepatuhan pajak. Sejalan dengan penelitian yang dilakukan oleh Sander et al. (2008) yang menyatakan bahwa kesadaran atas sanksi berpengaruh terhadap kepatuhan pajak. Penelitian tersebut dilakukan dengan metode eksperimen terhadap industri konstruksi. Hasil penelitian Alm (1995) juga menyatakan bahwa seseorang individu bersedia membayar pajak karena adanya rasa takut terhadap hukuman.

Penelitian-penelitian di atas menyatakan bahwa motivasi terbesar kepatuhan pajak ditentukan oleh perceived probability of audit/audit dan sanksi. Individu ketika merasa akan diaudit lebih hati-hati dalam melakukan tindakan sehingga, kemungkinan seseorang akan patuh terhadap aturan akan semakin tinggi. Di sisi lain jika ditemukan pelanggaran, sanksi yang diberikan akan lebih parah dibanding harus melaporkan dan membayar pajak dengan jumlah yang tepat. Adanya perasaan akan diaudit dan sanksi yang diterima lebih berat maka pilihan yang terbaik adalah dengan mematuhi ketentuan yang telah ditetapkan. Berdasarkan uraian di atas maka dapat dihipotesiskan: $\mathrm{H}_{1}$ : Perceived probability of audit berpengaruh positif terhadap kepatuhan pajak.

$\mathrm{H}_{2}$ : Sanksi berpengaruh positif terhadap kepatuhan pajak.

Penelitian-penelitian yang dilakukan sebelumnya menyatakan bahwa ketika perceived probability of audit dan sanksi meningkat maka akan meningkatkan tingkat kepatuhan pajak. Hasil penelitian Thurman 1991 dalam Trivedi et al. (2003) berbeda dengan penelitian sebelumnya, menyatakan bahwa audit dan penalty tidak cukup menjelaskan derajat tingkat ketidakpatuhan pajak. Penelitian yang dilakukan oleh Jhonson et al. (2010) menyatakan audit (monitoring) tidak akan meningkatkan kepatuhan pajak jika tidak diterapkan dengan beberapa kebijakan. Hasil penelitian Cumming et al. (2009) sejalan dengan dua penelitian sebelumnya, tingginya denda dan peningkatan frekuensi audit akan menimbulkan tindakan penipuan yang akan memicu rendahnya kepatuhan pajak.

Penelitian tersebut mengindikasikan bahwa seseorang berusaha untuk menghindari pajak. Penghindaran bisa saja dilakukan dengan memberikan imbalan terhadap petugas pajak atau dengan melakukan penipuan-penipuan lain. Perasaan akan di audit dan sanksi yang berat tidak akan memiliki pengaruh terhadap kepatuhan pajak, namun sesorang 
akan berusaha untuk mencari jalan lain dalam menghindari pajak. Dibutuhkan faktor lain yang dapat meningkatkan hubungan antara perceiveid probability of audit dan sanksi dengan tingkat kepatuhan pajak.

Penelitian yang dilakukan Alm et al. (1995) juga membuktikan bahwa deterrence faktor tidak cukup efisien untuk meningkatkan kepatuhan pajak karena probabilitas aktual wajib pajak UMKM untuk diperiksa dan didenda masih cukup rendah. Hasil penelitian Alm dan McClellan (2012) menyatakan bahwa moral merupakan faktor terpenting meningkatkan kepatuhan pajak. Hanno dan Violette (1996) menyatakan bahwa keputusan taat atau tidak taat terhadap aturan pajak merupakan sebuah perilaku kognitif yang berada dalam perilaku kontrol individu. Pembuatan keputusan kepatuhan pembayaran pajak didasarkan pada sikap terhadap kepatuhan yang berkembang sepanjang waktu melakui akuisisi keyakinan tentang hasil dari kepatuhan dan evaluasinya.

Pemeriksaan dan denda pajak akan dapat meningkatkan kepatuhan hanya bersifat sementara pada periode pemeriksaan saja. Pemeriksaan dan sanksi tidak akan optimal karena keterbatasan jumlah pemeriksa pajak. Oleh karena itu, dalam meningkatkan kepatuhan pajak pemerintah harus mengkombinasikan program pemeriksaan dan sanksi dengan mempertimbangkan perilaku wajib pajak (tax morale) di negara tersebut. Hipotesis pada penelitian ini dapat dirumuskan sebagai berikut:

H3 : Tax morale memoderasi hubungan positif antara perceived probability of audit dengan keputusan kepatuhan pajak, hubungan tersebut semakin kuat ketika tax morale wajib pajak semakin tinggi.

H4 : Tax morale memoderasi hubungan positif antara sanksi dengan keputusan kepatuhan pajak, hubungan tersebut semakin kuat ketika tax morale wajib pajak semakin tinggi.

\section{Desain penelitian}

Desain penelitian ini bisa dilihat pada Gambar 1.

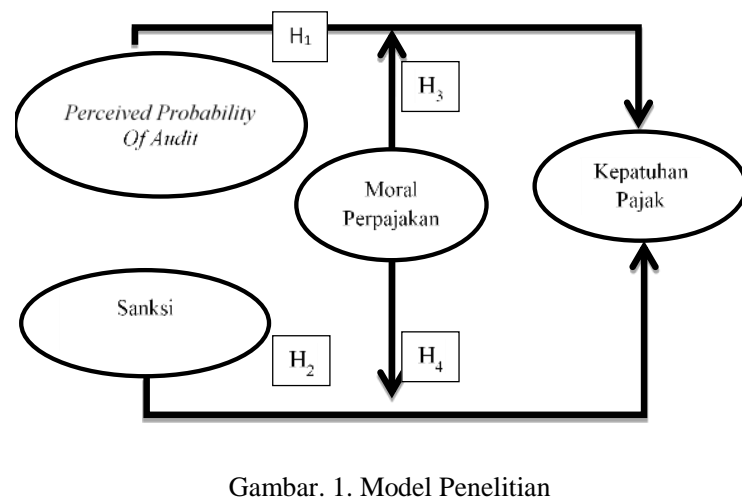

\section{Metode Penelitian}

\section{Sampel penelitian}

Penelitian ini dilakukan di DIY, dengan metode pengumpulan data melalui survei. Populasi dalam penelitian ini adalah pelaku UMKM di Daerah Istimewa Yogyakarta (DIY) yaitu wilayah Kabupaten Sleman, Kulon Progo, Bantul, Gunung Kidul, dan Kota Yogyakarta. Kriteria sampel pada penelitian ini adalah pemilik UMKM di DIY, yang memiliki omset di bawah 4,8 Millyar.

\section{Definisi operasional dan instrumen pengukuran}

Kepatuhan pajak yaitu tindakan membayar dan melaporkan pajak dengan jumlah dan waktu yang tepat. Instrumen pengukuran yang digunakan dalam penelitian ini diadobsi dari penelitian Bobek et al. (2013).

Moral perpajakan merupakan motivasi instrinsik pada wajib pajak untuk mematuhi dan membayar pajak sehingga bisa berkontribusi secara sukarela pada penyedia barang-barang publik. Instrumen pengukuran untuk melihat moral perpajakan diadobsi dari penelitian Barone dan Mocetti (2011).

Perceived probability of audit merupakan kondisi yang menggambarkan perasaan responden untuk diperiksa. Instrumen yang digunakan untuk melihat Perceived probability of audit dari penelitian Asnawi et al. (2010) yang dikembangkan dari instrumen Milliron dan Toy (1988).

Sanksi pajak merupakan akibat yang timbul ketika wajib pajak tidak patuh dalam perhitungan, pelaporan, dan pembayaran pajak. Pengukuran sanksi di adopsi dari penelitian Liu (2014). 


\section{Metode analisis data}

Metode analisis data yang pertama dilakukan dengan pengujian instrumen untuk melihat validitas dan reliabilitas. Pengujian asumsi klasik dilakukan sebelum pengujian hipotesis, penelitian ini menggunakan uji asumsi klasik yaitu uji normalitas, uji heteroskedasitas dan uji multikolinearitas. Metode statistik yang digunakan untuk menguji hipotesis penelitian adalah analisis regresi dengan bantuan perangkat lunak SPSS. Metode regresi yang digunakan untuk menguji hipotesis langsung menggunakan analisis regresi berganda sedangkan metode regresi yang digunakan untuk menguji hipotesis moderasi menggunakan Moderated Regression Analysis (MRA).

\section{Hasil Penelitian}

Penelitian ini melakukan penyebaran kuesioner pada seluruh Kota dan Kabupaten di DIY. Tingkat pengembalian kuesioner dapat dilihat pada Tabel 1 .

Table 1

Tingkat Pengembalian Kuesioner

\begin{tabular}{lrr}
\hline \multicolumn{1}{c}{ Keterangan } & Jumlah & Persentase \\
\hline Kuesioner yang dibagikan & 183 & $100 \%$ \\
Kuesioner kembali & 160 & $87,43 \%$ \\
Kuesioner yang tidak lengkap (tidak & 5 & $2,73 \%$ \\
dapat digunakan) & & \\
Kuesioner dapat diolah awal & 155 & $84,70 \%$ \\
Kuesioner data outlier & 37 & $20,22 \%$ \\
Kuesioner yang di analisis & 118 & $64,48 \%$ \\
\hline
\end{tabular}

Berdasarkan kusioner yang dapat dianalisis dapat dilihat karakteristik responden seperti terlihat pada Tabel 2.

Table 2

Karakteristik Responden

\begin{tabular}{lrr}
\hline Karakteristik Responden & Jumlah & Persentase \\
\hline Jenis kelamin & & \\
Laki-laki & 38 & $32,20 \%$ \\
Perempuan & 80 & $67,80 \%$ \\
Jumlah & 118 & $100,00 \%$ \\
Jenis Usaha & & \\
Industri Makanan & 40 & $33,90 \%$ \\
Kerajinan & 59 & $50,00 \%$ \\
Lainnya & 19 & $16,10 \%$ \\
Jumlah & 118 & $100,00 \%$ \\
Pendidikan & & \\
Tidak tamat SMA & 8 & $6,78 \%$ \\
Tamat SMA & & \\
Diploma & 47 & $39,83 \%$ \\
S1 & 24 & $20,34 \%$ \\
& 34 & $28,81 \%$ \\
\hline
\end{tabular}

\begin{tabular}{lrr}
\hline S2 atau lebih & 5 & $4,24 \%$ \\
Jumlah & $\mathbf{1 1 8}$ & $\mathbf{1 0 0 , 0 0 \%}$ \\
\hline
\end{tabular}

Pengujian validitas dan reliabilitas dalam penelitian ini dilakukan sebelum melakukan analisis data. Pada penelitian ini, uji validitas menggunakan analisis faktor. Hasil analisis faktor menunjukkan bahwa dari pertanyaan untuk melihat perceived probability of audit digunakan tiga indikator pertanyaan, sanksi seluruhnya valid, moral perpajakan yang digunakan empat item petanyaan, dan kepatuhan pajak digunakan empat item petanyaan sehingga total pertanyaan yang lolos uji validitas sebanyak 17 item petanyaan. Semua nilai convergent validity sudah di atas 0,4 dan signifikan pada level kepercayaan 5\% (Heir et al., 2014). Penelitian ini juga sudah memenuhi uji reliabilitas dengan nilai cronbach's alpha terendah pada variabel perceived probability of audit 0,634 sudah di atas 0,6 .

Pengujian asumsi klasik dilakukan setelah uji validitas dan uji reliabilitas. Uji normalitas data menunjukkan data berdistribusi normal karena nilai unstandardized residual sebesar 1.196 dan tidak signifikan $(0,114)$ lebih besar dari 0,05 $(\mathrm{P}>0,05)$. Tabel 3 menunjukkan hasil uji multikolinearitas.

Table 3

Hasil Uji Multikolinearitas

\begin{tabular}{lcc}
\hline \multicolumn{1}{c}{ Variabel } & Tolerance & VIF \\
\hline Perceived probability of audit & 0,955 & 1.047 \\
Sanksi & 0,924 & 1.082 \\
Moral perpajakan & 0,890 & 1.123 \\
\hline
\end{tabular}

Dari Tabel 3 dapat dilihat bahwa setiap variabel dalam penelitian ini tidak mengandung multikolinearitas. Pengujian heteroskedastisitas dalam penelitian ini juga sudah menunjukkan angka yang tidak signifikan. Nilai signifikansi untuk setiap variabel sebesar 1,000 lebih besar dari nilai alpha 0,01 sehingga penelitian ini tidak terjadi gejala heterokedastisitas. Pengujian hipotesis dapat dilihat pda Tabel 4.

Table 4

Hasil Uji $t$

\begin{tabular}{lcccc}
\hline \multicolumn{1}{c}{ Variable } & $\mathbf{R}^{2}$ & $\begin{array}{l}\text { Unstandardized } \\
\text { Coefficient Beta }\end{array}$ & t Hitung & p-Value \\
\hline $\begin{array}{l}\text { Konstanta } \\
\begin{array}{l}\text { Perceived } \\
\text { probability of } \\
\text { audit }\end{array}\end{array}$ & $0,133,914$ & 6,467 & 0,000 \\
Sanksi & 0,204 & 2,543 & 0,012 \\
\hline
\end{tabular}


Hipotesis 1 menyatakan bahwa perceived probability of audit berpengaruh positif terhadap kepatuhan pajak. Pada Tabel 4 pengaruh perceived probability of audit terhadap kepatuhan pajak UMKM menunjukkan nilai signifikansi 0,012 yang lebih kecil dari 0,05 $(\alpha)$ dan nilai koefisien regresi sebesar 0,204, $\mathrm{t}_{\text {hitung }}=2,543$. Dilihat dari nilai nilai koefisien regresi bernilai positif sesuia dengan nilai yang diharapkan untuk hipotesis pertama, hasil uji tersebut menjelaskan hipotesis pertama terdukung. Perceived probability of audit memiliki pengaruh terhadap kepatuhan pajak, semakin besar kemungkinan di audit tingkat kepatuhan pengusaha UMKM untuk membayar pajak semakin tinggi.

Hasil penelitian ini sejalan dengan penelitianpenelitian sebelumnya seperti penelitian yang dilakukan oleh Liu (2014) yang menyatakan bahwa adanya kemungkinan audit akan meningkatkan kepatuhan wajib pajak. Hal yang serupa juga terdapat dari hasil penelitian yang dilakukan oleh Asnawi et al. (2009) yang menyatakan bahwa perceived probability of audit berpengaruh terhadap keputusan kepatuhan pajak. Penelitan eksperimen yang dilakukan oleh Ghosh dan Crain (1996) juga membuktikan bahwa ketika perceived probability of audit tinggi maka tingkat ketidakpatuhan rendah.

Hipotesis 2 menyatakan bahwa sanksi berpengaruh positif terhadap kepatuhan pajak. Variabel sanksi memiliki nilai koefesien regresi sebesar 0,086 , $\mathrm{t}_{\text {hitung }}=$ 2,171 dengan nilai $\mathrm{p}=0,032$ di bawah tingkat signifikansi $\mathrm{p}<0.05$, hasil uji tersebut menjelaskan hipotesis kedua terdukung. Semakin besar sanksi yang diberikan pemerintah semakin tinggi tingkat kepatuhan pajak pengusaha UMKM. Hasil pengujian juga menunjukkan bahwa pengaruh perceived probability of audit dan sanksi terhadap kepatuhan pajak dapat dijelaskan sebesar 13,3\%.

Penelitian saat ini memberikan hasil yang serupa dengan beberapa penelitian terdahulu. Penelitian yang dilakukan oleh Palil dan Ahmad (2011) menunjukkan hasil bahwa tingginya tingkat sanksi dapat meningkatkan tingkat kepatuhan pajak. Hal serupa juga dinyatakan oleh hasil penelitian Sander et al. (2008) yang menyatakan bahwa kesadaran atas sanksi berpengaruh terhadap kepatuhan pajak. Penelitian yang dilakukan oleh Alm (1995) juga menyatakan bahwa seseorang individu yang bersedia membayar pajak karena adanya rasa takut terhadap hukuman.

Hipotesis 3 menyatakan bahwa moral perpajakan memoderasi hubungan positif antara perceived probability of audit dengan keputusan kepatuhan pajak, hubungan tersebut semakin kuat ketika moral perpajakan wajib pajak semakin tinggi. Tabel 5 menyajikan pengujian moderasi. Pengujian hipotesis dilakukan dengan menggunakan MRA.

Table 5

Ringkasan hasil analisis dengan MRA

\begin{tabular}{|c|c|c|c|c|}
\hline $\begin{array}{l}\text { Persamaan } \\
\text { regresi }\end{array}$ & Keterangan & $\begin{array}{l}\text { Unstandardize } \\
\text { d Coefficient } \\
\text { Beta }\end{array}$ & $\begin{array}{l}\mathbf{t} \\
\text { Hitun } \\
\mathrm{g}\end{array}$ & $\begin{array}{l}\text { p- } \\
\text { Valu } \\
\text { e }\end{array}$ \\
\hline $\begin{array}{l}\mathrm{TC}=\alpha+\mathrm{PPA}+\beta \mathrm{TM} \\
+ \\
\beta \mathrm{PPA} * \mathrm{TM}+\varepsilon\end{array}$ & $\begin{array}{l}\text { Perceived } \\
\text { probability of } \\
\text { audit } * \text { Moral } \\
\text { perpajakan } \\
\text { Adj } \mathrm{R}^{2}=0.186 \\
\mathrm{~F}=9.929\end{array}$ & 0.026 & 1.049 & 0.296 \\
\hline $\begin{array}{l}\mathrm{TC}=\alpha+\mathrm{S}+\beta \mathrm{TM}+ \\
\beta \mathrm{S}^{*} \mathrm{TM}+\varepsilon\end{array}$ & $\begin{array}{l}\text { Sanksi*Mora } \\
\text { l perpajakan } \\
\text { Adj } \mathrm{R}^{2}=0.203 \\
\mathrm{~F}=10.940\end{array}$ & 0.008 & 0.621 & 0.536 \\
\hline
\end{tabular}

Tabel 5 menunjukkan bahwa nilai yang tidak signifikan karena $\mathrm{p}=0,296$ lebih besar dari 0,05 dan $\mathrm{t}$ hitung 1,049 dengan pengaruh $(\beta) 0,26$, varian kepatuhan pajak dapat dijelaskan oleh varian perceived probability of audit dan moral perpajakan sebesar $22,4 \%$, sisanya dijelaskan oleh varian faktor lain di luar model. Dengan demikian hasil penguijian tersebut tidak bisa membuktikan bahwa moral perpajakan memperkuat hubungan antara perceived probability of audit terhadap kepatuhan pajak. Hipotesis 3 dalam penelitian ini ditolak.

Penelitian ini tidak bisa membuktikan beberapa penelitian terdahulu. Hasil penelitian hanya menyatakan bahwa moral perpajakan memiliki pengaruh langsung terhadap kepatuhan pajak, moral perpajakan tidak mampu untuk memperkuat hubungan antara perceived probability of audit terhadap kepatuhan pajak. Moral perpajakan yang tinggi tidak perlu didukung lagi oleh adanya kemungkinan diaudit, kepatuhan membayar pajak berasal dari kesadaran individu itu sendiri. Sesuai dengan teori penalaran moral Kohlberg (1969) individu yang telah ada pada tahap post conventional akan berperilaku patuh atas kesadaran individu tersebut. Tindakan kepatuhan akan muncul karena mereka memang sadar tindakan tersebut merupakan sesuatu yang harus mereka lakukan, tidak akan mempertimbangkan apakah akan diaudit atau tidak.

Penelitian yang dilakukan oleh Lewis at al. (2009) juga menyatakan bahwa kebijakan audit sebagai cara meningkatkan kepatuhan pajak akan lebih efektif dilakukan pada negara yang tingkat moral pajaknya rendah seperti pada kasus Italia. Hal tersebut berbeda dengan moral perpajakan di Indonesia yang umumnya memiliki tingkat moral tinggi, sehingga moral 
perpajakan tidak mampu memoderasi hubungan perceived probability of audit dengan tingkat kepatuhan pajak. Penelitian ini mampu membuktikan ketika moral pajak seseorang sudah tinggi mereka tidak akan melihat lagi apakah ada ancaman akan diaudit atau tidak. Peningkatan moral perpajakan Indonesia harus lebih dimotivasi, untuk meningkatkan kesadaran serta pendapatan negara dari sektor pajak.

Ketidakberahasilan penelitian ini mendukung hipotesis mungkin juga disebabkan oleh beberapa hal. Pertama, penelitian sebelumnya dilakukan pada perusahaan besar atau wajib pajak individu sedangkan, penelitan saat ini dilakukan di UMKM. Kelemahan kedua karena UMKM memilki tiga kriteria usaha mikro, kecil, dan menengah, kebanyakan responden yang mengisi kuesioner penelitian ini usaha mikro sehingga pengetahuan mereka di bidang rasa tanggung jawab mereka masih minim. Tidak terdukungnya hipotesis bisa juga disebabkan karena PP 46 Tahun 2013 tidak mengatur mengenai batas minimal omset dan lama usaha berdiri, ketika kewajiban pajak dibebankan terhadap pemilik UMKM yang masih baru, mereka akan keberatan untuk membayar pajak. Kelemahan yang terakhir disebabkan oleh penelitian yang menggunakan survei, sehingga memungkinkan seseorang bias dalam mengisi jawaban dari pertanyaan.

Hipotesis 4 menyatakan bahwa moral perpajakan memoderasi hubungan positif antara sanksi dengan keputusan kepatuhan pajak, hubungan tersebut semakin kuat ketika moral perpajakan wajib pajak semakin tinggi.Pengujian hipotesis dilakukan dengan menggunakan MRA.

Tabel 5 menunjukkan bahwa nilai yang tidak signifikan karena $\mathrm{p}=0,536$ lebih besar dari 0,05 dan $\mathrm{t}$ hitung 0,621 dengan pengaruh $(\beta) 0,008$ varian kepatuhan pajak dapat dijelaskan oleh interaksi varian sanksi dan moral perpajakan sebesar $20,3 \%$, sisanya dijelaskan oleh varian faktor lain di luar model. Dengan demikian hasil penguijian tersebut tidak bisa membuktikan bahwa moral perpajakan memperkuat hubungan antara sanksi terhadap kepatuhan pajak. Penelitian ini menolak hipotesis 4 .

Hasil penelitian ini tidak bisa membuktikan beberapa penelitian terdahulu. Hasil pengujian penelitian menunjukkan bahwa responden yang memiliki nilai moral tinggi tidak perlu diancam dengan sanksi. Hal tersebut sesuai dengan teori tahapan penalaran moral Kolberg (1969) individu yang memiliki moral tinggi akan berlaku patuh sesuai dengan kesadaranya sendiri. Kepatuhan tersebut bukan karena ketakutan akan sanksi namun karena kesadaran mereka sendiri. Dilihat dari hasil pengujian pengaruh langsung moral perpajakkan (faktor perilaku) lebih signifikan dibanding faktor ekonomi.

Beberapa hal yang memungkinkan efek moderasi tidak terdukung karena PP No. 46 tahun 2013 tidak mengatur batas minimal omset dan lama UMKM berdiri. Hal tersebut memungkinkan bahwa PP 46 tahun 2013 masih membingungkan bagi pemilik UMKM, dan di lapangan juga ditemui bahwa dinas perindustrian dan koperasi juga belum memahami secara jelas penerapan PP 46 tahun 2013. Ancaman akan diaudit dan sanksi yang akan diberikan belum mempertimbangkan nilai moral perpajakan di Indonesia. Penyebab lainya karena ketidakseimbangan sampel, umumnya responden dalam penelitian ini kebanyakan usaha mikro.

\section{Kesimpulan, Implikasi, Keterbatasan, Dan Saran}

\section{Kesimpulan}

Berdasarkan hasil pengujian dalam penelitian ini dapat disimpulkan hal-hal sebagai berikut:

1) Hasil pengujian empiris menunjukkan bahwa perceived probability of audit berpengaruh langsung terhadap kepatuhan pajak. Dengan demikian $\mathrm{H}_{1}$ terdukung. Hasil ini sesuai dengan hasil penelitian sebelumnya yang dilakukan oleh Liu (2014).

2) Hasil pengujian empiris menunjukkan bahwa sanksi memiliki pengaruh terhadap kepatuhan pajak. Dengan demikian $\mathrm{H}_{2}$ terdukung. Hasil ini sesuai dengan hasil penelitian yang telah dilakukan oleh Palil dan Ahmad (2011), Sander et al. (2008) dan Alm (1995) terkait dengan sanksi perpajakan.

3) Hasil pengujian empiris menunjukkan bahwa moral perpajakan tidak bisa memoderasi hubungan perceived probability of audit terhadap kepatuhan pajak. Dengan demikian $\mathrm{H}_{3}$ tidak terdukung. Hasil ini sesuai dengan teori tahap penalaran moral (the stages of moral reasoning) dari Kohlberg (1996) dan hasil penelitian yang dilakukan oleh Lewis et al. (2009).

4) Hasil pengujian empiris menunjukkan bahwa moral perpajakan tidak signifikan memiliki pengaruh moderasi terhadap hubungan sanksi dan kepatuhan pajak. Dengan demikian $\mathrm{H}_{4}$ tidak terdukung. Hasil ini sesuai dengan teori tahap penalaran moral (the stages of moral reasoning) dari Kohlberg (1996). Kepatuhan pajak berasal 
dari kesadaran seseorang bukan karena adanya sanksi.

Tidak terdukungnya beberapa hipotesis dalam penelitian ini mungkin disebabkan oeleh faktor-faktor lain yang dapat mempengaruhi kepatuhan pajak. Pada hasil penelitian ini umumnya moral perpajakan sehingga, tidak bisa memperkuat hubungan dari perceived probability of audit dan sanksi terhadap kepatuhan.

\section{Implikasi}

Penelitian memberikan beberapa implikasi yaitu:

1) Hasil penelitian ini membuktikan bahwa deterrence faktor seperti audit dan sanksi dapat meningkatkan kepatuhan pajak, sebaiknya pemerintah mempertimbangkan audit dan sanksi pada konteks PP 46.

2) Penentu kebijakan harus mengatur regulasi yang lebih jelas mengenai perpajakan di UMKM terutama pada implementasi PP 46 tahun 2013.

3) Implementasi PP 46 tahun 2013 terhadap UMKM akan lebih efektif dilaksanakan dengan memberikan penyuluhan atau gambaran tentang apa, bagaimana, dan manfaat pajak bagi masyarakat.

\section{Keterbatasan}

Interpretasi dari kesimpulan hasil penelitian ini perlu mempertimbangkan keterbatasan dalam penelitian ini. Adapun keterbatasan dalam penelitian ini adalah sebagai berikut:

1) Kemungkinan masih ada bias penilaian moral karena penilaian moral perpajakan hanya dilakukan dengan memberikan kuesioner anonim.

2) Penelitian ini dilakukan dalam konteks PP 46 tahun 2013 sehingga generalisasi harus dilakukan secara hati-hati.

3) Penelitian ini menggunakan sampel penelitian yang berasal dari satu wilayah saja, yaitu DIY sehingga pembaca harus hati-hati dalam mengeneralisasi hasil penelitian.

4) Penelitian ini hanya menggunakan tiga variabel sehingga dimungkinkan adanya variabel-variabel lain yang dimungkinkan memiliki pengaruh terhadap kepatuhan pajak.
Saran

Berdasarkan keterbatasan-keterbatasan yang ada serta pengembangan penelitian selanjutnya, beberapa saran dan rekomendasi dapat diberikan, antara lain:

1) Mencari penilaian lain untuk mengurangi bias penilaian moral.

2) Menentukan ukuran sampel dengan mempertimbangkan effect size.

3) Penelitian selanjutnya dapat menambah objek penelitian dengan beberapa UMKM di wilayahwilayah lain.

4) Menambah variabel persepsi wajib pajak terhadap petugas pajak dan variabel keadilan pemerintah dalam mendistribusikan pajak.

\section{References}

Allingham, M.G. dan A. Sandmo. (1972). Income Tax Evasion: A Theoretical Analysis. Journal of Public Economics, 1(3), 323-338.

Alm, J dan C., McClellan. (2012). Tax Morale and Tax Compliance From the Firm's Perpective. Kyklos, 65(1),1-17.

Alm, J. (1991). A Perspective on the Experimental Analysis of Taxpayer Reporting. The Accounting Review, 66(3), 577-593.

Asnawi, M., Z. Baridwan, Supriyadi, dan E. Nahartyo. (2009) Analisa Keputusan Kepatuhan Pajak: Strategi Audit Random, Perceived Probability of Audit dan Pemahaman Etika Pajak (Studi Eksperimen Laboratorium). Paper presented at the Simposium Nasional Akuntansi 12, Palembang.

Barone.G., dan S. Mocetti. (2011). Tax Morale and Public Spending Inefficiency. Int Tax Public Finance, 724-749.

Bobek, D., Donna, Charles F. Kelliher, dan Amy M. Hageman. (2013). Analyzing the Role of Social Norms in Tax Compliance Behavior. Journal of Business Ethics, 115:451-468.

Budiningrum, E. W. (2014). Pengaruh Norma-Norma Sosial Terhadap Perilaku Kepatuhan Pajak Usaha Mikro, Kecil, Dan Menengah (UMKM). Tesis, Universitas Gadjah Mada, Yogyakarta.

Cahyonowati, Nur. (2011). Model Moral dan Kepatuhan Perpajakan: Wajib Pajak Orang Pribadi. JAAI, 15(2), 161-177.

Cahyonowati, N., D., Ratmono, dan Faisal. (2012). Peranan Etika, Pemeriksaan, dan Denda Pajak Untuk Meningkatkan Kepatuhan Wajib Pajak Orang Pribadi. Jurnal Akuntansi dan Keuangan Indonesia, 136-153.

Campin Suzanne, Jo Barraket, dan Belinda Luke. (2013). MicroBusiness Community Responsibility in Australia: Approaches, Motivations and Barriers. Journal of Business Ethics, 115:489-513.

Chen, D., F. C. Lee dan J. Mintz. (2002). Taxation, SMEs and Entrepreneuship. STI Working Paper, 19.

Cooper, Donal R., dan Pamela S. Schindler. (2006). Business Research Method. New York: McGraw-Hill Compaines, Inc., 9th Edition. 
Cummings, R. G., J. M.Vazzquez, M. McKee, dan Torgler, B. (2007). Tax Morale Effect Tax Compliance: Evidance From Surveys and an Artefactual Fiel Experiment. Journal of Economic Behavior \& Organization, 447-457.

Ghosh, D. dan T. L. Crain. (1996). Experimental Investigation of Ethical Standards and Perceived Probability of Audit on Intentional Noncompliance. Behavioral Research in Accounting, 8(Supplement 1996), 219-244.

Hair, J. F., Willam, C. B., Barry, J. B., dan Rolph E. A. (2014). Multivariate Analysis. Pearson Education Limited: England.

Hanno, M., D.,dan G., Violette. (1996). An Analysis of Moral and Social Influances on Taxpayer Behavior. Behavioral Research in Accounting

Harinurdin Erwin. (2009). Perilaku Kepatuhan Wajib Pajak Badan, Bisnis \& Birokrasi. Jurnal Ilmu Administrasi dan Organisasi, MeiAgustus, 16(2), 96-104.

Hartono Jogiyanto. (2013). Metode Penelitian Bisnis Salah Kaprah dan Pengalaman-Pengalaman. Edisi 6. BPFE Yogyakarta.

Hendricks, K., R. Amit dan D. Whistler. (1997). Business Taxation of Small and Medium-sized Enterprises in Canada. Ottawa: Department of Finance Working Paper, 97-11.

Hyun., J.K. (2005). Tax Compliance in Korea and Japan: Why are they Different? Preliminary draf for discussion at the seminar held by Policy Reseach institute Ministry of Finance, Japan.

Jhonson, C. D., Masclet dan C., Montmarquette. (2010). The Effect of Perfect Monitoring of Matched Income on Sales Tax Compliance: An Experimental Investigation. National Tax Journal, 121-148.

Kamleitner, B., C. Korunka dan E. Kirchelr (2010). Tax Compliance of Small Business Owners A review. International Journal of Behavior \& Research, 18(3), 330-351.

Kamus Besar Bahasa Indonesia online. (n.d) Retrieved Oktober 22, 2013, from http://kamusbahasaindonesia.org/moral.

Kamus Besar Bahasa Indonesia online. (n.d) Retrieved Oktober 22, 2013, from http://kamusbahasaindonesia.org/patuh.

Kamus Besar Bahasa Indonesia online.(n.d) Retrieved Oktober 22, 2013, from http://kamusbahasaindonesia.org/sanksi.

Laporan keuangan Pemerintah Pusat tahun 2012 (Audited). Mei 2013

Lewis, A., Sonia, C., John, C., dan Philip, J. (2009). Individual, Cognitive and Cultural Differences in Tax Compliance: UK and Italy Compared. Journal of Economic Psychology, 30: 431-445.

Liu, Xin. (2014). Use Tax Compliance: The Role of Norms, Audit Probability, and Sanction Sevarity. Academy of Accounting and Financial Studies Journal, 18(1), 65-80.

Mardiasmo. (2011). Perpajakan. Edisi Revisi 2011. Yogyakarta: Andi.

Milliron, V., C. dan Daniel R, T. (1985). Tax Compliance: An Investigation Key Features. The Journal of The American Taxation Association(Spring), 84-104.
Molero, J., C., dan Pujol, F. (2012).Walking Insede the Potential Tax Evader's Mind: Tax Morale Does Matter. Journal Bussnis Ethics, 105:151-162.

Normala, Siti. (2004). The Influence of Penalties on Taxpayers' Compliance: A Comparison of The Theoretical Models. Journal of Economics and Management, 81-113.

Palil.M dan A. Fariq Mustapha. (2011). The Evaluation and Concept of Tax Compliance in Asia and Europe. Australian Journal of Basic and Applied Sciences, 5(11), 557-563.

Penas, I.L., dan Penas, S., L. (2010). The Determinants of Tax Morale in Comparative Perspective: Evidence From European Countries. European Journal of Political Economy, 26: 441-453.

Peraturan Pemerintah Republik Indonesia, Nomor 46 Tahun 2013, Tentang Pajak Penghasilan atas Penghasilan dari Usaha yang Diterima atau Diperoleh Wajib Pajak yang Memiliki Peredaran Bruto Tertentu.

Pertiwi, D.,. (2013). Memahami Penyebab Kepatuhan Pajak: Faktor-Faktor Perilaku Manusia. Skripsi, FEB UGM.

Praag. C. M., dan Peter H., V. (2007). What Is the Value of Entrepreneurship? A Review of Recent Research. Small Business Economics, 29(4), 351-382.

Sanders, D.L., Phillip M.J.R dan Govind S.I. (2008). Influence Accountability and Penalty Awareness on Tax Compliance. Journal of The American Taxation Association 30(2), 1-20.

Setiyani, Rina. (2008). Deterrent Effect Penyidikan Pajak Asian Agri Group Terhadap Peningkatan Kepatuhan Wajib Pajak Sektor Industri dan Perkebunan Kelapa Sawit. Tesis, Universitas Indonesia, Jakarta.

Song, Y.D., dan Yarbrough, T.,E. (1978). Tax Ethics and Tax Payer Attitudes: a Survey. Public Administration Review, 442-452.

Statistik Usaha Mikro, Kecil dan Menengah (UMKM) Tahun 20102011, Bagian Data-Biro Perencanaan Website: www.depkop.go.id; e-mail: bagdat@depkop.go.id.

Trivedi, V.U., Lynn, B., dan Shehata, M. (2003). Impact of Personal and Situasional Factors on Taxpayer Compliance: an Experimental Analysis. Journal of Business Ethics, 47: 175-197.

Torgler, B., dan Scheneider, E. (2004). Attitudes Towards Paying Taxes In Austria: An Emperical Analysis. Emperica, 231-250.

Torgler, B. (2004). Moral Suasion: An Alternative Tax Policy Strategy? Evidence From a Controlled Field Experiment in Switzerland. Econ. Gov 5:235-253.

(2006). The Importance of Faith: Tax Morale and Religiosty. Journal of Economic Behaviour \& Organization, 61:81109.

Undang-Undang Republik Indonesia Nomor 20 Tahun 2008 Tentang Usaha Mikro, Kecil, dan Menengah.

Zatnika, A., M. (2014). Penerimaan Pajak 2013 Pendapatan pajak UKM 2013 capai Rp 328,94 triliun. http://nasional.kontan.co.id/news/pendapatan-pajak-ukm-2013capai-rp-32894-triliun. Diakses 17 September 2014. 